\title{
Study on Online Teaching of College Physical Education in the Era of Big Data
}

\author{
Jv JIN ${ }^{1}$, Hongqian Wang ${ }^{2, *}$

\begin{abstract}
${ }^{1}$ School of Public Finance and Administration, Harbin University of Commerce, Harbin, Heilongjiang 150028, China
${ }^{2}$ School of Public Finance and Administration, Harbin University of commerce, Harbin, Heilongjiang 150028, China

*Corresponding author. Email: hongqian1451329039@qq.com
\end{abstract}

\begin{abstract}
In the era of big data, online teaching has become an important symbol of the modernization of university physical education. The concept of modern university physical education is to impart physical knowledge, technology and skills to students so as to effectively develop their bodies, enhance their physique and cultivate their moral will. It not only enriches the teaching materials, but also effectively stimulates the students' learning initiative. The development of the online model of college physical education ensures the learning effect of the majority of college students and promotes the process of physical education informatization. It is undeniable that this new teaching mode also has its own shortcomings. Analyses and discussions of these problems will help find solutions for the comprehensive construction and development of the teaching of college physical education in the era of big data.
\end{abstract}

Keywords: The era of big data, College physical education, Online teaching.

\section{BACKGROUND AND CONSIDERATION: NEW TRENDS IN ONLINE COLLEGE PHYSICAL EDUCATION}

In the 21 st century, under the background of the rapid development of science and technology, this technology has been involved in all aspects of social life with unprecedented technological advantages. In a sense, it has fundamentally shaped the ecology of today's social life, and the university physical education is no exception. From the earliest "MOOC" and "online classroom" to the today's "flipped classroom" and "mixed classroom" and other diversified teaching forms, all of them are various forms by which the big data technology penetrates the field of education. In terms of MOOC innovation, the PE Teaching and Research Department encourages teachers to integrate their MOOC into the school's online teaching, so as to promote and develop each other, so as to better serve students and improve the teaching quality. The big data technology realizes the online education development of college physical education, makes the design of college physical education curriculum flexible, and increases college students' interest in learning.[1] In addition, the big data technology has the basic characteristics of massive information, open sharing and online construction. In a sense, it has drastically impacted the traditional university physical education like a "tsunami" and accelerated the informatization of university physical education. From this point of view, the online teaching of college physical education in the era of big data has become a trend. It not only changes the traditional teaching, but also significantly promotes the interaction between teachers and students and the technical standardization[2]. Rational reflection on this fact will not only help effectively keep pace with the reform of the big data technology and pave the way for deepening the reform of college physical education, but also help explore the regularity of college physical education in the new era[3].

\section{OPPORTUNITY AND INNOVATION: NEW DEVELOPMENT OF ONLINE TEACHING IN COLLEGE PHYSICAL EDUCATION}

In 2018, the Ministry of Education issued Educational Informatization Action Plan 2.0, and proposed that a large-scale "Internet plus Education" platform should be established by 2022[4]. A year later, the Ministry of Education, together with more than ten departments such as the National Development and Reform Commission and the Cyberspace Administration of China, issued the Guidance on Promoting the Sound 
Development of Online Education, which proposed a teaching resource development mode of "supporting schools to do research and formulate specific measures, and effectively ensured the inclusion of qualified online courses into the education and teaching system"[5]. In 2020 , when introducing the work of online teaching in colleges and universities, $\mathrm{Wu}$ Yan, Director of the Department of Higher Education, clearly pointed out that "online teaching has become an important direction for the development of higher education in China and even in the world"[6]. As an important part of public basic subjects in colleges and universities, the characteristic of being online for the teaching of physical education has become the direction of the reform and development of college physical education[7].

Multiple online teaching modes such as online classroom, classroom in the air, MOOC and smart classroom, have become the "new normal" of college physical education in the era of big data, thus raising higher requirements for the teachers of college physical education. They should not only use the existing network facilities and teaching resources to quickly carry out teaching activities, but also need to overcome the differences and difficulties in physical education between universities and colleges and other schools, and improve the degree of informationization of college physical education[8]. The realization of online teaching of college physical education is more conducive to the sharing of physical education teaching resources, the renewal of teaching methods, the iteration of teaching mode, and the construction of online virtual teaching environment. At the same time, it helps to provide customized and targeted teaching solutions for college physical education through online data intelligent analyzing system[9].

\section{PRACTICE AND PATH: NEW PRACTICE OF ONLINE TEACHING OF COLLEGE PHYSICAL EDUCATION}

The realization of online teaching of college physical education can also represent the new direction of online education practice innovation[10].

In the traditional PE classroom model, teachers, as the owners of educational theory and professional skills, often have the absolute authority in the teaching process; As the object of education, students can only passively accept the teacher's "admonition" as the audience, and their individual subject value cannot be effectively brought into play. The two sides present obvious binary opposition as the subject and the object. In the long run, this kind of "indoctrination" teaching based on teacher's explanation and demonstration gradually makes students lose interest and enthusiasm in physical education, resulting in the embarrassing situation where "students like physical exercise but dislike the course of physical education". In the era of big data, relying on the development of artificial intelligence, mobile Internet and other technologies, in the online teaching of physical education, to some extent, teachers and students are simplified into ordinary "users" in the intelligent terminal, and the boundary between the subject and the object between teachers and students is broken[11]. In this process, students' ability as the subject is constantly improved with the help of technical force. For example, they can freely choose their favorite courses according to their own interests, or use intelligent search engines to conveniently choose the information they need. From this point of view, in the historical context of Internet decentralization, online physical education, due to its feature of having large-scale open network, places students in the center of teaching and emphasizes the educational concept of "student-centered", which makes the whole teaching activity change from "teaching" to "learning". It not only helps to increase students' participation in sports teaching activities, but also makes them become the main body of learning[12].The object of PE teaching is students, and the effect of PE teaching should be reflected on the students. Students have a strong plasticity, physical education teaching every idea and steps, will directly affect the growth of students.

In the past classroom teaching, restricted by the length of teaching materials, access to information and other aspects, the teaching content of college physical education has obvious limitations so that students' interest in physical education cannot be effectively stimulated. Relying on the rapid development of digital technology and mobile Internet technology, online education platforms such as "MOOC", "Wisdom Tree" and "Xue Xi Tong", make up for the shortcomings of traditional college physical education because of their large information capacity and rich and colorful content, and provide the possibility to meet the diversified needs of both teachers and students[13]. For physical education teachers can combine the teaching to the excavation of the relevant network resources online, such as classical audio information, video data movement skills, and combined with the traditional physical education curriculum resources, as the course content provide a steady stream of "food", also let students learn material no longer stay on the textbook, effectively increase the depth and width of classroom teaching. For students, they can also search a large number of online courses through online courses, providing rich resources for independent learning. It can be said that in the era of big data, through the effective integration of a variety of teaching resources, not only the breadth of theoretical knowledge of college physical education teaching content has been expanded, but also the theoretical professionalism has been enhanced and the higher and higher requirements of physical education teaching have been effectively met. 
For a long time, the starting point of students' learning is set subjectively by physical education teachers, which shows the obvious characteristics of standardization and unification. In fact, this kind of "uniform" teaching method badly ignores the individual differences between students. Some students with strong comprehension ability can master it quickly, while some students with poor physical coordination need a long time to master the movements. Finally, the specific teaching arrangement of the physical education curriculum is seriously divorced from the actual situation of students. It is not conducive for students to master the sports knowledge and skills better. In the era of big data, online physical education perfectly combines information technology with modern classroom and makes full use of the achievements of information technology so that students can be taught in accordance with their aptitude" based on their individual differences. Additionally, the method of "hierarchical education" with a personalized learning way is interpreted through online teaching. In the process of learning through the online platform, if students encounter complex or difficult sports actions or skills, they can watch the teaching video by pause, deceleration or playback, so as to form the early concept construction of sports skills [14]. In addition, VR technology can also be used to obtain detailed information of sports professional movements from all angles and in all directions, so as to increase students' intuitive feeling of technical movements. It can be seen that in the era of big data, online physical education not only provides students with more forms of expression and expanded content, but also brings greater space for development to meet the needs of students at all levels and students' personalized learning, solves the contradiction between unified teaching and personalized learning, and helps to optimize and improve the effect of physical education. The reflection of a right teaching effect on students is not only the strength of external muscles, the perfect development of bones and the sound of internal organs, but also the overall symmetry and coordinated development.

\section{CHALLENGE AND REFLECTION: NEW PROBLEMS IN ONLINE TEACHING OF COLLEGE PHYSICAL EDUCATION}

In the process of online teaching, many teachers and students actively explore new ways to realize the online teaching of college physical education, devote themselves to online teaching activities, and make great efforts to ensure the quality of teaching and protect the physical and mental health of college students. But at the same time, this new teaching mode also has its own problems. For instance, it is unable to master the learning practice situation through the online education system and to really guarantee the quality of learning and so on[15].
At the same time, the discipline of physical education has certain particularity. For example, when the hand is extended to a certain position, the upper arm drives the forearm. Under the direct guidance of teachers, students need to form motor memory through the perception of different parts of the body to master motor skills. Online sports teaching is mainly in the form of watching videos and electronic texts. Students can't follow the teacher face to face for action practice, and can't experience the teacher's action correction or confrontational practice. From this point of view, online physical education, to a certain extent, makes the body practice teaching which should be flexible and changeable become the indoctrinated teaching based on "listening and watching", which cannot make students master the correct movement skills, and would reduce the students' sense of physical and mental experience, and is not conducive to the maintenance of students' interest in learning and the cultivation of lifelong sports consciousness[16].

This problem have been highlighted in the mature teaching platform. Furthermore, the online teaching of college physical education has higher requirements for teaching hardware, such as the recognition of action, the particularity of online course sharing resources, etc., which to a certain extent limits the process of online development of physical education. And these problems also become the main obstacles restricting the online development of college physical education in the future[17].

\section{CONCLUSION}

The significance of big data mainly lies in the use of huge data information, and the professional processing of data, so as to discover the important value contained in it. Big data is applied in physical education teaching research value is hidden in the phenomenon of physical education teaching practice, problems or performance characteristics, using the data of the era of large data reserve and technical tools, develop into visual data symbols, through the analysis, processing, found that can make use of the value of reveals the teaching phenomena and explore the nature of physical education teaching rule. Thus, in the era of big data, the online teaching mode of physical education relying on the Internet, artificial intelligence and other modern information technologies promotes the innovation of college physical education teaching technology reform[18]. For college teachers and students, it is not only a new opportunity for teaching reform, but also a new challenge. Colleges and universities across the country have accumulated relevant experience in the field of online sports teaching, but also found relevant problems. Under the background of clear realization of overall innovation in physical education teaching, targeted solutions to relevant problems and summarizing 
experience and lessons can comprehensively promote the positive practice of online sports teaching in colleges and universities.

\section{ACKNOWLEDGMENTS}

Time is like water, the mouth is like a shuttle, recalling the study and life of these years, there are gratitude, harvest, bitterness, helplessness and reluctance, and I will face a new life turning point, my heart has inexplicable emotions, there are too much gratitude, there are too many feelings. This paper was completed under the guidance of my tutor Professor JV JIN for many times. From the topic selection to the structure arrangement, from the content to the text embellishment, she has condensed a lot of painstaking efforts. I was deeply moved by Miss Jinju's meticulous and responsible spirit.Here, please allow me to express my sincere thanks to your esteemed teacher Jv JIN! My beloved teachers, dear classmates, because of you, I have no regrets in the three years, because of you, I will summon up courage, stride forward, to meet the future wonderful world.I would like to thank my classmates and friends who have accompanied me during the three years of New Year's greetings. I would like to thank them for their intentional suggestions and opinions. With their support, encouragement and help, I can fully spend the three years of study and life.

\section{REFERENCES}

[1] Zhang Yaotian, Zhou Qingshan. Impact and Integration: Reflections on the Reconstruction of Teachers' Capability in the Context of "Smart Classroom" for University Ideological and Political Education [J]. Journal of Hubei Normal University (Philosophy and Social Sciences), 2019, 39 (03): 98-103.

[2] Liu Wen. A Study of Online Teaching System, Teaching Contents and Methods of the Physical Education Course in Colleges and Universities [J]. Heilongjiang Science, 2021, 12 (05): 120-121.

[3] Yang Hui, Liu Chen. Reflection on the Construction of Informationized Teaching Platform for College Physical Education [J]. Education and Teaching Forum, 2020 (50): 367-368.

[4] Ministry of Education. Notice of Issuing Educational Informatization Action Plan 2.0 by the Ministry of education [Z]. 2018.

[5] 11 departments including the Ministry of Education. Guidance on Promoting the Sound Development of Online Education issued by the Ministry of Education [Z]. 2019.

[6] Ministry of Education of the People's Republic of China. Introducing the Situation of Online
Education in Primary and Middle schools and Colleges and Universities During the COVID-19 Period and the Next Work Considerations [EB/OL]. (2020-5-14)http://www.moe.gov.cn/fbh/live/2020/5 $1987 /$

[7] Wang Guoliang, Zhan Jianguo. Benefits and Implementation Strategies of Introducing Flipped Classroom into Physical Education [J]. Journal of Beijing Sport University, 2016, 39 (02): 104-110.

[8] Xiao Ertong. Exploration of Blended Learning Mode in College Physical Education under the background of "Internet plus" [J]. China Audio-Visual Education, 2017 (10): 123-129.

[9] Zhang Jianwei, Tang Weidong. Exploration and Thinking of College Physical Education Teaching Mode Based on MOOC [J]. China School Physical Education (Higher Education), 2016, 3 (01): 72-78.

[10] Li Lin, Li Chenglong. Practice and Reflection on Online Physical Education in Regular Colleges and Universities [j]. The Science Education Article Collects (first ten issues), 2020 (10): 112-113.

[11] Guo Shuai, Feng Xiaoli. Teaching and Learning of College Physical Education in the Age of Information Technology: Concept and Evidence [J]. Journal of Physical Education, 2021, 28 (01): 108-113.

[12] Yin Zhenghui, Shao Kai. University Intelligent Physical Education: Practical Dilemmas, Exploration, and Reform and Innovation [J]. Journal of Shenyang Agricultural University (Social Science Edition), 2020, 22 (02): 178-183.

[13] Li Moutao. Discussion on the Reform of Physical Education in Colleges and Universities in the Context of "Internet plus" [J]. Journal of Mudanjiang University, 2021, 30 (01): 119-124.

[14] Han Hangkang. Research and Analysis of MOOC Physical Education in Colleges and Universities in the Era of Big Data $[\mathrm{J}]$. Contemporary Sports Technology, 2020, 10 (36): 129-131.

[15] He Jinglin, Chen Xi. Innovative Ways of College Physical Education from the perspective of Internet [J]. Contemporary Sports Technology, 2020,10 (35): $119-120+125$.

[16] Liu Bo, Fu Honghao. Practice and Prospect of Online Physical Education Teaching in Colleges and Universities in the Context of Education Informatization [J]. The Education of Innovative Talents, 2021 (01): 16-22.

[17] Yang Hui, Liu Chen. Reflection on the Construction of Informationized Teaching Platform 
for College Physical Education [J]. Education and Teaching Forum, 2020 (50): 367-368.

[18] Chen Yu. Practice of Blended Learning Mode in Physical Education in Colleges and Universities in the Context of "Internet plus" [J]. Sports Vision, 2020 (07): 35-36. 